\title{
Gemeentestudies: 'n Snel ontwikkelende veld van studie
}

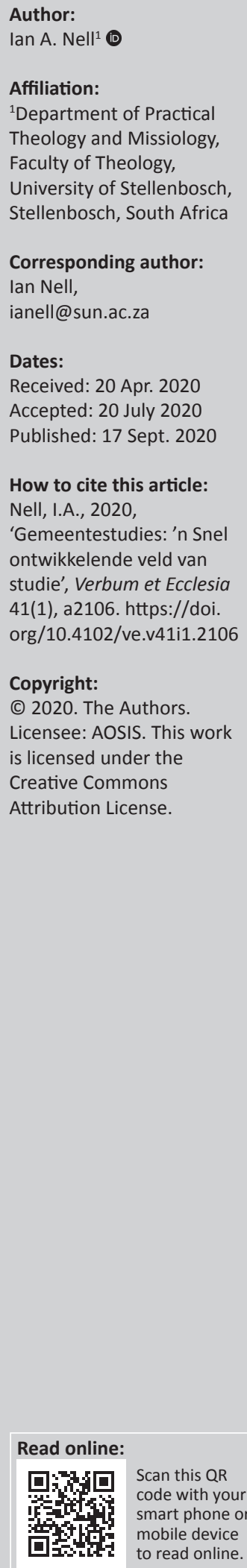

Congregational studies: A rapidly developing field of study. Congregational studies are not so simple to define. This may be related to the relative novelty of the discipline, but also to the variety of people who practise it and the equally wide range of angles to the field. The purpose of this article is to look at various stages in the development of the field of congregational studies in the South African context, and more specifically within the Dutch Reformed Church over the past 50 years. The phases can be described as follows: the initial church-building phase, followed by the phase where the dynamics and identity of faith communities came into focus, and then by a phase in which the focus shifted to congregational studies specifically within the African context and greater focus on the empirical investigation of congregations in the form of various modes of congregational analysis, as well as the advent of a missional approach to congregations. A further and ever-evolving phase is the move towards a more aesthetic perspective of the field, known as a theo-dramatic approach. Together with the last phase, we just entered what I would call the post- COVID-19 phase. One can see massive changes in congregational ministry since the COVID-19 virus started to spread in South Africa. Overnight, ministers and church boards had to adapt to online modes of being and doing church and I am very sure this will be an enormous shift. In future we will certainly speak about church before and after COVID-19.

Intradisciplinary and/or interdisciplinary implications: This article looks at congregational studies from a historical perspective and reaches the conclusion that it is still a relatively young and developing discipline that can benefit from an aesthetical approach to the field. This challenges the traditional perspective that congregational studies are only interested in the analysis of congregations. This scientific approach strengthens newer hermeneutical interpretations of congregations. The fields involved are congregational studies, sociology and ethnography through the lens of critical qualitative research.

Keywords: Congregational studies; Dutch Reformed Church; identity of faith communities; missional congregations; Theo-drama; congregational analysis; church-building; ministry.

\section{Inleidend}

Gemeentestudies is nie so eenvoudig om te definieer nie. Dit hou moontlik verband met die relatiewe nuutheid van die dissipline, maar ook met die verskeidenheid mense wat dit praktiseer en die ewe groot verskeidenheid invalshoeke tot die gebied (Ammerman 2009:562). Gemeentes is in die laaste 50 jaar op verskillende maniere bestudeer, maar 'n selfbewuste verwysing na die gebied vind 'n mens eers sedert die sewentigerjare in die Verenigde State van Amerika (VSA) en Duitsland. In die VSA het ' $n$ werkgroep van Amerikaanse geleerdes in 1979 onder leiding van Robert Lynn byeengekom as deel van die Godsdiens-afdeling van die Lily Endowment. Hulle het met verloop van tyd die naam 'Project Team for Congregational Studies' gekry. Die meeste van hierdie geleerdes is tot vandag steeds aktief deel van die groep (Nieman 2012:134).

In Duitsland is Gemeindeaufbau (gemeentebou) die eerste keer deur Bruno Gutmann in 1925 gebruik in die titel van sy boek Gemeindeaufbau aus dem Evangelium (Gutmann 1925). Alhoewel die begrip ook in die derde tese van die Barmen-verklaring van 1934 voorkom, is dit eers sedert die sewentigs wat daar werklik 'n nuwe oplewing van en belangstelling in die vakgebied onder Duitse teoloë gekom het. Dit was gedurende die Luasanner Konferenz der Evangelikalen van 1974 wat die begrip Gemeindeaufbau weer in erns opgeneem is en wel vanuit 'n piëtistiese invalshoek. Dit was egter Fritz en Christian Schwartz wat in 1984 die eerste teologie van gemeentebou die lig laat sien het met hul publikasie Theologie des Gemeindeaufbaus (Schwarz \& Schwarz 1984). In Nederland was dit Jan Hendriks Verlange en vertroue: Het hart van gemeentebouw (2008), Henk de Roest En de wind steekt op. Kleine ecclesiologie van de hoop (2005) en Rein Brouwer Geloven in 
gemeenschap: Het verhaal van een Protestantse geloofsgemeenschap (2009) wat belangrike werke lewer op die gebied van gemeentestudies.

\section{Nader aan 'n definisie}

Alhoewel daar nie 'n eenvormige definisie van die vakgebied bestaan nie, is daar wel 'n aantal sake waaroor geleerdes dit eens is wanneer die fokus op gemeentestudies as vakgebied val. Die meeste geleerdes sal waarskynlik saamstem met die vertrekpunt dat gemeentestudies bestaan uit ' $n$ gedissiplineerde en holistiese ondersoek van gemeentes aan die hand van 'n verskeidenheid navorsingsmetodes (Carroll \& Dudley 1986:3). Dit is dus meer as 'n paar los opmerkings oor wat in gemeentes gebeur. Ondersoeke is daarop gemik om op 'n geordende wyse navorsing te doen oor wat werklik in groepe gebeur, sowel dít wat voor die hand liggend is as dít wat verborge is.

Daar is dus 'n poging om 'n akkurate weergawe te gee van die interaksie van verskillende aspekte van 'n gemeente op soek na bepaalde patrone en strukture. Wat van grondliggende belang is in hierdie tipe ondersoeke is dat die integriteit van die gemeente bewaar moet word en dit nie gereduseer mag word tot ' $n$ illustrasie van geleerde teorieë of die onderwerp van akademiese nuuskierigheid nie (Browning 1994:192). 'n Holistiese benadering tot gemeentes vra dus dat verskillende perspektiewe van gemeentes gebruik moet word en gewoonlik word daar van die hulpmiddele van die sosiale wetenskappe gebruik gemaak. Hierdie beskrywende gereedskap word gewoonlik aangevul deur teologiese raamwerke vir die interpretasie van die data en dan is dit 'n geval dat die teologie en die sosiologie hande vat in die interpretasieproses (Stokes \& Roozen 1991:185).

Praktiese teologiese navorsers benader die gebied gewoonlik vanuit drie invalshoeke (Nieman 2012:135). Wat die navorsingsituasie betref, word die gebied verstaan as 'n lokus van navraag en ondersoek oor spesifieke vorme van religieuse lewe met 'n meer spesifieke fokus op die religieuse groep as eenheid van ontleding. As navorsingsliteratuur word op die gebied besin oor 'n wye verskeidenheid diverse ondersoeke. Ons kan dit beskryf as ' $n$ histories veranderende liggaam van ondersoeke wat verslag gee van verskillende vorme van religieuse lewe. As navorsingsmetodologie word die verskillende benaderings en stratgieë wat werk, geïnkorporeer in die gebied met die oog op beter begrip van hierdie plaaslike religieuse byeenkomste.

Met ' $n$ beter idee van wat onder gemeentestudies verstaan word, staan ek vervolgens by verskillende fases in die ontwikkeling van die gebied in die Suid-Afrikaanse konteks stil en meer spesifiek soos wat dit op akademiese gebied in die Nederduits Gereformeerde (NG) Kerk ontwikkel het. Die fases sou soos volg beskryf kon word: Die eerste fase is 'n gemeenteboufase, gevolg deur die fase waar die dinamika en identiteit van geloofsgemeenskappe in fokus gekom het. Dit is opgevolg deur ' $n$ fase waarin die fokus verskuif het na gemeentestudies spesifiek in die Afrika-konteks en ook 'n groter fokus op die empiriese ondersoek na gemeentes in die vorm van verskillende vorme van gemeente-ontledings, asook die koms van wat bekend staan as missionale teologie. 'n Verdere en steeds ontwikkelende fase is die skuif na'n meer estetiese invalshoek op die gebied, bekend as 'n teodramatiese benadering.

\section{Gemeentebou en gemeentevernuwing}

Reeds aan die begin van die tagtigerjare het Malan Nel (1982) 'n voordrag by die Werkgemeenskap vir Praktiese Teologie in Suid-Afrika gelewer, wat hy "n Program vir vernuwing' getitel het en waarin hy die eerste treë gegee het op die weg van gemeentebou en -vernuwing. In 1985 lewer hy 'n ongepubliseerde referaat by die Sentrum vir Voortgesette Teologiese Opleiding met die titel 'Bedieningstrukture' as opvolg van sy vorige werk oor gemeentes. In 1994 verskyn sy bekende boek Gemeentebou en kan 'n mens duidelik sy aansluiting by die Duitsers se Gemeindeaufbau hierin vind. Die eerste deel van die boek noem hy 'Gemeentebou: Teologiese perspektiewe', terwyl deel 2 na gemeentebou as "n Prosesmatige bediening' kyk en die derde deel aandag skenk aan 'Gemeentestrukture'.

Volgens Burger (1991) werk gemeentebou 'met 'n redelike eenvoudige program'. Hy beskryf dit as volg:

Hoewel daar heelwat onderlinge verskille ten opsigte van detail was, het dit feitlik oral gerus op twee hoekpilare. Ten eerste moes soveel lidmate as moontlik gehelp word om tot 'n nuwe geestelike oorgawe te kom en te leer hoe om hulle getuienis effektief te lewer. Ten tweede is sterk klem gelê op die gemeenskap van die gelowiges, oftewel koinonia. (bl. 15)

Nel werk in deel 1 met 'n sterk teologiese benadering tot gemeentebou en vind aansluiting by verskillende boumetafore in die Ou en die Nuwe Testament. Volgens hom is gemeentebou en gemeentevernuwing ten diepste God se werk en staan dit alles binne die perspektief van God se koninkryk. Die sentrale prakties teologiese vertrekpunt van 'kommunikatiewe handelinge in diens van die Evangelie' speel 'n sentrale rol deur die ganse boek. Sy boek word ook in 2004 in Engels vertaal met die titel Who are we? Understanding and finding identity in the local church.

In 2015 sien 'n hersiene weergawe van sy 2004-publikasie die lig met die titel Identity-driven churches: Who are we, and where are we going? (Nel, Nell, Schoeman \& Tucker 2015), en kry hy ook drie medewerkers by wat bydraes lewer oor die volgende onderwerpe: 'Leadership in faith communities - linking with word and sacrament' (Ian Nell), 'Describing a congregation looking for certain markers' (Kobus Schoeman) en 'Discovering the church's forgotten identity - a key to developing missional congregations' (Roger Tucker).

Nel kan ook as 'n voorloper vir die empiriese fase van gemeentestudies beskou word, aangesien elkeen van sy boeke ook 'n afdeling oor gemeente-ontledings bevat. 
Nel vind veral sterk aansluiting by die werk van Callahan met die titel: Twelve keys to an effective church (1983). Sy empiriese werk het 'n sterk kwantitatiewe inslag wat gewoonlik uit 'n situasie- en omgewingsdiagnose en 'n gemeentediagnose en -evaluering bestaan. Sy metode bestaan uit onderhoudvoering en ontledingsvraelyste. Daar is dus goeie interaksie tussen teorie en praktyk in sy prakties teologiese nadenke oor gemeentes.

\section{Strategies teologiese beplanning}

Jurgens Hendriks word in 1985 na die Fakulteit Teologie by die Universiteit Stellenbosch beroep met die spesifieke opdrag om die vakgebied van gemeentestudies te ontwikkel. Hy kry die beroep op grond van tien jaar se ervaring van gemeentevernuwing in gemeentes in die Noord-Kaap, waar hy predikant was van die NG gemeente Upington. Hendriks sluit sterk aan by die bestuurswetenskappe en skryf 'n boek met die titel Strategiese beplanning in die gemeente: Die beginsels en praktyk van gemeentevernuwing (Hendriks 1992b). Ná 'n oorsig oor verskillende kerkmodelle maak hy, soos Nel, van die boumetafoor as basisteorie gebruik. In die daaropvolgende hoofstuk ontwikkel hy 'n praktykteorie vir die diens van die kerk aan die hand van aanvullende koinonia-verbande.

Die sterk punt van sy teorie vind mens egter in hoofstuk 4, waarin hy'n strategie voorstel waarvolgens die praktykteorie geïmplementeer kan word, wat hy 'strategiese-teologiese beplanning' noem. In dié verband sluit hy by modelle en strategieë vanuit die bestuurswêreld aan en ontwikkel hy 'n model wat uit vier fases bestaan: die probleemidentifiseringsfase wat uit 'n diagnostiese aktiwiteit bestaan, 'n skeppende fase wat uit 'n teologiese aktiwiteit bestaan, 'n beplanningsfase wat uit 'n organisatoriese aktiwiteit bestaan en 'n implementeringsfase wat met 'n bedieningsaktiwiteit te make het.

In dieselfde jaar as wat Strategiese beplanning in die gemeente verskyn, tree Hendriks ook op as redakteur van 'n boek met die titel Gemeentes vertel: Verandering in ' $n$ Christelike geloofsgemeenskap (1992a), waaraan verskillende outeurs meewerk en aan die hand van verskillende verhale en vorme van gemeente-ontledings vertel wat in hul gemeentes aan die verander is en die moontlike agtergrond en oorsake daarvan bespreek. Dit staan natuurlik in noue verband met die politieke omwentelinge aan die einde van die tagtigerjare en begin negentigerjare. Die boek sluit insigte van gemeentes vanuit die platteland, dorpe, voorstedelike gebiede en selfs die middestad in.

\section{Die dinamika en identiteit van geloofsgemeenskappe}

Ná 'n studiebesoek aan die VSA aan die einde van die tagtigerjare skryf Coenie Burger 'n boek met die titel Die dinamika van 'n Christelike geloofsgemeenskap: Nuut gedink oor gemeentes (1991). Hy is opgewonde oor interessante verwikkelinge in die VSA op die gebied van gemeentestudies.
Volgens hom het die oorspronklike Amerikaanse model van gemeentebou, ook bekend as die sogenaamde 'Church Growth-beweging', hierin 'n belangrike rol gespeel, maar het daar by hulle, soos in Suid-Afrika, 'n behoefte ontwikkel om gemeentes en hul werking op 'n dieper vlak beter te verstaan. Hy beskou sy boek as 'n poging om 'n beskeie antwoord te vind op die vraag: Hoe werk 'n gemeente of geloofsgemeenskap regtig? Volgens hom help die dogmatiek ons om te verstaan wat die ideale kerk behoort te wees (sistematiese ekklesiologie), maar help dit ons nie om te verstaan hoe dit in die praktyk beplan en verwesenlik behoort te word nie (prakties teologiese ekklesiologie). Dit gaan dus oor ' $n$ belangstelling in die doeltreffende funksionering van die kerk en gemeentes.

'n Nuwe fase het aangebreek waar insigte uit die ontwikkelinge in die sosiale wetenskappe, soos die bestuurswetenskap, sosiale sielkunde en sosiologie, ons oë geopen het vir die dinamika wat daar in groepe, organisasies en gemeenskappe in hul alledaagse funksionering bestaan. Volgens Burger wou hy hierdie insigte in sy 1991-publikasie verder voer, hulle teologies evalueer en daarna prakties teologies benut met die oog op die praktyk van ons kerklike lewe. Hy doen dit deur 'n basisteorie oor die dinamika van 'n geloofsgemeenskap te ontwikkel aan die hand van vier prosesse wat tegelyk en in ewewig in beweging gehou moet word. Die vier prosesse is volgens hom: (1) 'n gedeelde visie van die koninkryk van God, (2) 'n vaste geloofsverbintenis aan dié visie, (3) 'n sorgsame gemeenskapslewe (koinonia) waarin mense mekaar op hierdie pad ondersteun en (4) 'n sterk oriëntasie tot dade en doen, in die wete dat die kern van die Christelike lewe diens is.

Hy bestee dan een hoofstuk aan elk van die vier prosesse deur telkens sewe rubrieke (vrae) te behandel. Hulle is die volgende: 'n kort omskrywing van wat presies bedoel word met 'n betrokke term of aspek; 'n Bybelse fundering van die saak met hier en daar verhelderende perspektiewe uit die geskiedenis van die kerk; 'n operasionalisering van die perspektief in prakties teologiese bedieningsoogmerke; 'n evaluering van die situasie in die NG Kerk ten opsigte van hierdie aspek; voorlopige besinning oor hoe die betrokke aspek die beste bedien sou kon word, met ander woorde die vraag na die implikasies hiervan vir die bedieningspraktyk; teologiese kontrolering of toetsing van die betrokke aspek en sy funksionering vanuit die vier eienskappe van die ware kerk soos die Apostoliese Geloofsbelydenis dit omskryf; en netelige vrae ten opsigte van die funksionering van die aspekte waaraan aandag gegee sal moet word. Dit is ' $n$ werk wat ons geslag teoloë baie gehelp het om iets van ons onvermoë om die snel veranderende tye te verstaan ' $n$ bietjie onder woorde te help bring en ietwat van 'n greep te probeer kry op die begeleiding van gemeentes.

Vier jaar ná sy 1991-boek volg Burger dit op met nog 'n boek wat by die tema van gemeentestudies aansluit: Gemeentes in transito: Vernuwingsgeleenthede in 'n oorgangstyd (1995). In hierdie boek maak hy erns met die konteks waarin 
die kerk haarself te midde van oorgangstye bevind. Hy wys daarin:

$[D]$ at daar juis in so ' $n$ tyd, by al die onsekerheid en ontwrigting en pyn wat so 'n oorgangstyd meebring, ook geweldige geleenthede en unieke moontlikhede vir diepgaande vernuwing loskom. (bl. 9)

Hy sluit veral by die werk van die antropoloog Victor Turner aan om die unieke aard van die oorgangstye te beskryf. Turner (1969) werk met die onderskeid tussen wat hy noem 'n communitas-situasie en 'n societas-situasie. Beginnende by die laaste een, sou 'n societas-situasie dui op 'n fase van voorspoed, goeie strukturering en geordendheid in die ontwikkeling van 'n samelewing of groep mense. Die gemeenskap oefen dus goeie beheer uit oor sy probleme en daar word 'n groeifase beleef.

Hierteenoor word 'n communitas-situasie gekenmerk deur onsekerheid en oorgang. Vaste sekerhede en reëls maak plek vir ongestruktureerdheid en 'n sterker bewussyn van emosies en ervarings. Daar word selfs soms van 'anti-structure' gepraat, en baie mense se ervaring van 'n communitas-situasie is aanvanklik negatief as gevolg van die gebrek aan struktuur. Volgens Burger (1995:26) kan dit egter ook 'n baie betekenisvolle tyd word waarin mense die geleentheid kry om nuut na hul eie lewensin en lewenswaardes te kyk. Vanuit 'n perspektief van hoop beskryf hy dan in 'n paar hoofstukke hoe die anatomie van so 'n oorgangstyd lyk en in watter mate die potensiaal bestaan om verdiepte verhoudings te ontwikkel en daarmee saam ook 'n verdiepte spiritualiteit. Hy bestee aandag daaraan om te praat oor kreatiewe grenservarings, ook bekend as liminaliteit, en hoe 'n nuwe begrip van God, ons medemens en ons wêreld in so 'n fase 'n moontlikheid word.

Nog vier jaar later skryf Burger 'n omvattende werk oor gemeentes en die bediening met die titel Gemeentes in die kragveld van die Gees: Oor die unieke identiteit, taak en bediening van die kerk van Christus (1999). 'n Mens hoor in die titel iets van Moltmann se werk oor die kerk: The church in the power of the Spirit: A contribution to messianic ecclesiology (1978), wat daarop dui dat Burger diepgaande nagedink het oor die identiteit en bediening van die kerk en in die proses uit verskeie bronne geput het, soos in sy omvattende biografie duidelik word. Hy poog in hierdie werk om gelowig na te dink oor gemeentes en ontwikkel 'n Bybels-teologiese visie van gemeente-wees, en wys vir ons hoe die beliggaming van die visie vergestalting vind in die komplekse, dinamiese beweging in die kragveld van die Gees deur die bemiddelingsgawes van die Gees en deur die vier bedienings van die gemeente en sluit die boek af met sy nadenke oor riglyne vir vernuwing in gemeentes. Tot vandag, reeds 20 jaar later, beskou ek dit saam met die werke van Nel (2015) en Hendriks (2004) as die standaardtekste in gemeentestudies vir voorgraadse en nagraadse studente. Dit is wel jammer dat Burger se werk nooit in Engels vertaal is nie, wat dit ongelukkig vir 'n groot groep studente ontoeganklik maak.

\section{Gemeentestudies in 'n Afrika-konteks}

Ná die strategies teologiese fase van Jurgens Hendriks se navorsing (sien hier bo) breek 'n volgende fase in sy oeuvre aan met die verskyning van sy bekendste boek, Studying congregations in Africa, in 2004. Op grond van vele studiebesoeke aan die VSA vind Hendriks goeie aansluiting by veral die werk van James Hopewell se Congregation: Stories and structures (1987). Hy struktureer die boek rondom vier tipes ontledings wat van 'n gemeente gemaak kan word. Die vier ontledings is: (1) 'n konteksontleding, waar daar na die ekologie van die gemeente gekyk word en onder meer sake soos inkulturasie en die uitdaging van die Afrikakonteks saam met 'n bespreking van verskillende kulturele wêrelde aan die orde kom; (2) 'n identiteitsontleding, waar daar na die kultuur van 'n gemeente deur 'n aantal lense, soos demografie, die geskiedenis en erfenis van die gemeente en die aktiwiteite, simbole, rituele en verhale gekyk word; (3) 'n prosesontleding, waar die verhoudings en kommunikasie van die gemeente die fokus is en aspekte soos beplanning, leierskap en konflik in die gemeente van nader bekyk word; en (4) 'n hulpbronontleding, waarin lidmaatskap en verbintenis aan die gemeente, die finansiële bronne en die fisiek geboue en ruimtes die fokus van belangstelling is.

Alhoewel van die inligting in die boek reeds ' $n$ bietjie verouderd is, bly dit een van die handigste inleidings tot die gebied van gemeentestudies en is dit veral studente uit Afrika wat die boek baie waardevol vind. Deur NetAct (Network for African Congregational Theology), wat deur Hendriks en 'n paar kollegas in 2000 begin is, het hulle ook 'n goeie verspreidingsnetwerk ontwikkel waardeur gemeentestudies as gebied in Afrika bekendgestel is. Die boek self beskryf Hendriks as die produk van die samewerking met lede van NetAct, waardeur hulle ook poog om van die ernstigste probleme in Afrika (wat insluit armoede, korrupsie, MIV en Vigs en ekonomiese ongeregtigheid) aan te pak.

\section{Empiriese navorsing en gemeente-ontledings}

'n Empiriese benadering was van die begin af deel van Malan Nel se benadering tot gemeentestudies. Hy het telkens in onderafdelings van sy boeke aandag geskenk aan gemeenteontledings deur analitiese vrae te vra en gemeentelike diagnoses en evaluerings te doen, gewoonlik kwantitatief van aard, en dan ook strategiese planne vir vernuwing voor te stel. Die grootste bydrae op die gebied van kwantitatiewe empiriese navorsing in gemeentestudies het egter gekom van Kobus Schoeman en Jan Bischoff, wat sedert 1981 begin het met 'n sensusvraelys wat as 'Kerkspieël' bekendgestaan het, waarin hulle met behulp van kwantitatiewe metodologie 'n groot hoeveelheid statistieke oor die NG Kerk ingesamel en verwerk het. Aan die hand van hul navorsing kon met 'n redelike mate van akkuraatheid vasgestel word hoeveel NG Kerke daar in die land is, hoeveel predikante, wat hul 
ouderdomme is, ensovoorts. Hulle het verskeie opnames gemaak en het dit met verloop van tyd verder ontwikkel sodat daar ook vasgestel kon word wat die houdings van die leierskap (predikante en kerkraadslede) teenoor die samelewing en die kerk is. Hulle het gekyk na die kerk se rol en plek in die samelewing en die verskuiwings wat daar oor die afgelope paar dekades plaasgevind het.

In 2006 maak Schoeman die eerste keer van die National Church Life Survey (NCLS) gebruik. Die NCLS is 'n internasionale vraelys wat deur denominasies en gemeentes gebruik word met die doel om 'n stem aan gemeentelede te gee. Die vraelys het in 1991 in Australië ontstaan met 6700 gemeentes van 18 verskillende denominasies. Dit is in 1996 herhaal en uitgebrei na Nieu-Seeland waar nog 6900 gemeentes en 20 denominasies het. Die sukses van die vraelys het daartoe gelei dat dit ook in Engeland en die VSA gebruik is. In 2001 het ongeveer 1.2 miljoen aanbidders van vier verskillende lande aan die International Church Life Survey deelgeneem. Die deelnemersvraelys gee aan gemeentelede wat die eredienste bywoon die geleentheid om hul menings oor ' $n$ paar aspekte van gemeente-wees te lug. Die NCLS-vraelys is in 2006, 2010 en 2016 in die NG Kerk gebruik.

Die metodologie waarvan die vraelys gebruik maak, is ewekansige steekproefneming van $10 \%$ van die 1176 gemeentes in die NG Kerk, wat neerkom op deelname van 118 gemeentes. Die NCLS (Powell et al. 2012) gee 'n groot hoeveelheid inligting oor die verstaan van gemeentes vanuit die perspektief van lidmate. Elke gemeente het sekere sterk punte en die doel van die NCLS is om dié sterk punte te identifiseer vanuit die perspektief van die deelnemers aan die eredienste. Die gemeentelike lewe word gevolglik beskryf met betrekking tot tien sterk punte wat in vier verbindings gegroepeer word. Hierdie verbindings is geestelike verbindings, wat oor die private geestelike aktiwiteite van die aanbidders handel, met ander woorde oor hul deelname aan die aktiwiteite van die gemeente en die rol van die erediens in hul godsdienstige lewe; binneverbindings, wat verband hou met die aktiwiteite en verhoudings in 'n gemeente en met aspekte soos die gevoel van behoort en onderlinge sorg; buiteverbindings, wat die gemeente se betrokkenheid by die gemeenskap beskryf en aspekte soos die gasvryheid van die aanbidders en hul openheid jeens nuwe lidmate meet; en toekomstige verbindings, wat verband hou met die rol wat gemeentelike leierskap speel in die inspirasie van die aanbidders en 'n visie vir die toekoms van die gemeente (Schoeman 2015a:104-106).

Op grond van kategorisering en berekening van indeksgetalle vir elke sterk punt kan verskillende afleidings gemaak word oor die ware sterk punte van 'n gemeente en ook oor die groeipotensiaal van die gemeente. Hierdie syfers kan verder vergelyk word met byvoorbeeld die Presbiteriaanse Kerk in die VSA om te sien hoe denominasies met mekaar vergelyk met betrekking tot elk van die tien geïdentifiseerde sterk punte. Dit is duidelik dat die vraelys voordele bied wanneer dit kom by kwantitatiewe data en dit leen tot verdere kwalitatiewe ondersoeke.

\section{Missionale gemeentes}

In 2007 publiseer Nelis Niemandt 'n boek met die titel Nuwe drome vir nuwe werklikhede: Geloofsgemeenskappe in pas met 'n postmoderne wêreld. In aansluiting by Leonard Sweet se boek Soul tsunami wys hy daarop dat 'n geestelike getygolf besig is om die kerk te tref, wat die kerklike toneel blywend verander. Hy beskryf die storm wat besig is om die kerk te tref as 'the perfect storm' en dit kom as't ware in drie gedaantes na ons: postmodernisme, post-Christenheid en globalisering. 'n Hele nuwe wêreld is volgens hom besig om gebore te word en Niemandt is van oordeel dat nuwe maniere van kerkwees besig is om oor die wêreld heen te ontluik, wat bekendstaan as die 'emerging churches'. Volgens hom word hierdie ontluikende kerke gekenmerk deur 'n aantal geloofspraktyke. In aansluiting by die werk van Gibbs en Bolger (2005), met die titel Emerging churches: Creating Christian community in postmodern cultures, onderskei hy nege sulke geloofspraktyke: vereenselwiging met die lewe van Jesus Christus en sterk fokus op die koninkryk van God, transformasie van die sekulêre lewe deur afstand te doen van die skeiding tussen die geestelike en die fisiek, beklemtoning van kerklike gemeenskap, openheid teenoor vreemdelinge, oorvloedige diensbaarheid sonder bymotiewe, deelname deur gemeentelede, klem op kreatiwiteit, leierskap deur netwerke en nie deur hiërargiese strukture nie, en antieke geloofswaarhede in 'n byderwetse kleed.

Niemandt is ook 'n groot voorstander van 'n missionale benadering tot gemeentestudies en speel 'n leidende rol in ontwikkeling daarvan in die Suid-Afrikaanse konteks. Die missionale beweging het vanuit die Noord-Atlantiese konteks na Suid-Afrika in die vorm van die Suid-Afrikaanse Vennootskap vir Gestuurde Gemeentes gekom. Die oorsprong daarvan dateer uit 2004 met die eerste van 'n aantal besoeke deur Pat Keiffert aan ons land. Die eerste ontmoetings het meestal met die kerke van die Gereformeerde tradisie plaasgevind, en meer spesifiek met die NG Kerk.

Niemandt en Claassen (2012:2-4) gebruik die volgende opskrif in 'n artikel om die wese van hierdie beweging uit te spel: 'Van instandhouding na gestuurdheid - die buitelyne van 'n missionale teologie'. Hulle is van mening dat die tyd waarin ons onsself bevind 'n paradigmaskuif beleef en beskryf dit as ' $n$ skuif van instandhouding na sending (2012:2). Hulle verduidelik verskeie aspekte van ' $n$ missionale teologie en plaas dit sentraal in die ecclesia semper reformandakarakter van die Gereformeerde teologie. Hulle stem saam met Dawid Bosch se klem op God wat stuur, en wys hoe hierdie vertrekpunt ' $n$ radikale invloed op die praktyk van gemeentelike bediening het. Gemeentes leer dus om te onderskei waar die Drie-eenheid aktief is. 
Hierdie nuwe beweging het ongetwyfeld 'n groot invloed in die sfeer van die Gereformeerde kerke in Suid-Afrika. In 'n verslag aan die Algemene Sinode van Oktober 2013 het 'n dokument gedien met die titel 'Raamwerkdokument oor die missionale aard en roeping van die Nederduits Gereformeerde Kerk', waarin die slagspreuk 'van instandhouding na sending' gebruik word. Niemandt en Meiring, die samestellers van die verslag, skryf: 'Die kerk se primêre fokus is op die wêreld waarheen God haar gestuur het, en nie in die eerste plek op haar eie oorlewing gerig nie' (Algemene Sinode van die NG Kerk 2013:6).

\section{'n Teo-dramatiese benadering tot gemeentes}

Die ontstaan van hierdie benadering kan teruggevoer word na die werk van Rick Osmer, The teaching ministry of congregations (2005), en Nicholas Healy, Church, world and the Christian life: Practical-prophetic ecclesiology (2000). Die keuse vir 'n dramatologiese benadering hou verband met die behoefte aan praktiese teologie om handelingskommunikatiewe modelle vanuit die sosiale wetenskappe aan te vul met modelle wat in die geesteswetenskappe en kunste ontwikkel word. Die vrugbaarheid van hierdie tipe dialoë tussen teologie en die geesteswetenskappe het in resente dekades momentum begin kry met die opkoms van narratief as 'n belangrike kategorie in teologie en etiek. Die metaforiese kompleks van drama sluit aan by en behou die voordele van narratologie. Drama is 'n 'storie' van geaardheid met 'n intrige wat ontvou en klem lê op die eenheid van aksie oor ' $n$ tydperk. Maar dramas gaan ook verder deur die rol van aksie deur dramatiese realisering op die voorgrond te plaas. Dramas word met ander woorde nie net gelees nie, maar ook opgevoer. Toegepas op gemeentestudies is elke gemeente deel van 'n voortgaande dramatiese opvoering van die evangelie met verskillende rolspelers.

'n Verdere belangrike bydrae wat 'n teo-dramatiese benadering tot die veld van gemeentestudies lewer, hou verband met die belangrike rol wat teoloë en predikante as regisseurs in die drama speel. Ten spyte van die feit dat hulle veronderstel is om meer oor God en sy planne te weet as die ander akteurs, is dit ook so dat hulself 'n behoefte het om deur God gevorm te word. Saam met al die deelnemers moet daar na die primêre regisseur, die Gees van God geluister word, om eerlik te leef en die deelnemers aan die drama ook te lei om eerlik te leef. Elkeen moet sy en/of haar verantwoordelikheid opneem vir sy en/of haar roeping. Ons is gelyk in ons verantwoordelikheid en vrye wil voor God en almal word uitgedaag in hul rolle as akteurs. Dit kan predikante en teoloë se goddelike roeping wees om ander te help, maar slegs onder leiding van die Gees. Hierdie roeping moet vervul word met ' $n$ posisie van nederigheid en nie een van meerderwaardigheid nie, deur die voorbeeld van Jesus te volg.
Die metafoor van die wêreld as teater het 'n lang geskiedenis in die Westerse filosofie en teologie. Gedurende die tyd van die Reformasie het sowel Luther as Calvyn die metafoor gebruik. Calvyn het die metafoor van drama gebruik in 'n breedvoerige beskrywing van die skepping as die teater van God se glorie. In die Amerikaanse Protestantse teologie het Reinold Niebuhr kategorieë van drama gebruik om die onderlinge spel van menslike vryheid en bestemming in die geskiedenis te beskryf. Tog is dit die Rooms-Katolieke teoloog Hans Urs von Balthasar wat omvattend besin het oor die konseptualisering van die wêreld as teater waarin die goddelike en menslike dramas afspeel. Von Balthasar ontwikkel hierdie perspektiewe in Theo-drama: Theological dramatic theory (1988), waarin hy die Christelike teologie as 'n dramatologiese teorie vir die goeie onder woord bring.

Volgens Von Balthasar (1988:42) gaan mense met 'n tweevoudige behoefte teater toe: (1) Die drama is analoog met die spanninge van hul eie lewens en dien as 'n soort spieël wat hul eie lewenspatrone ophelder en interpreteer, en (2) die drama as geheel verteenwoordig oplossings en insigte in die dramatiese spanning wat lede van die gehoor daagliks beleef. Volgens hom is dit ' $n$ waardevolle en nuttige manier om oor die Christelike lewe na te dink, want in die teo-drama sien ons God se toetrede tot die verhoog van die wêreld deur sy Seun, Jesus Christus. Deur die deelname van Jesus Christus aan die God-mens-drama vind Christene hoe die dramatiese patrone van hul eie lewens opgeklaar en geïnterpreteer word. Dit gaan selfs verder, want as gelowiges bevind ons onsself nie maar net in die rol van toeskouers nie, maar ook as akteurs in die drama waar elkeen van ons ' $n$ spesifieke rol het om te speel.

Von Balthasar nooi ons uit om oor die teo-drama in trinitariese terme te dink: God die Vader is analoog aan die outeur van die teo-drama, die Seun as die hoofakteur en die Gees as die regisseur van die ensemble. Christene bevind hulself dus as deel van 'n teo-drama wat hulle nie self geskep het nie en waarvan die regisseur iemand anders as hulself is, en waarin hulle ook nie die hoofrolle speel nie. Nietemin, die rolle wat hulle wel gegee word om te speel, is werklik en verg al hul vaardigheid en kreatiwiteit. Daarom moedig Von Balthasar ons aan om aan ons rolle in die teo-drama te dink as analoog met die 'aktiewe ontvangs' van die akteurs in 'n opvoering. Aan die een kant 'ontvang' die akteurs hul spesifieke rolle in die ensemble van rolle en temas in die ontvouing van die samestelling van die drama as geheel. Hulle moet hulself dus gee en die spesifieke deel waaraan hulle in die drama deelneem, so goed 'dien' as wat hulle kan. Aan die ander kant is hulle 'aktief', aangesien die sukses van die opvoering van die kreatiwiteit en vaardigheid van die akteurs afhang. In die proses maak die akteurs van verskeie fisieke, emosionele en geestelike bronne gebruik om hul spesifieke rolle in die lewe te roep. Die draaiboekskrywer se teks bly 'ongeaktualiseer' sonder die dramatiese realisering van die akteurs wat dit alles in 'n dramatiese opvoering die lewe gee. Analoog hiermee, so redeneer Von Balthasar, is die Christelike lewe een van aktiewe ontvanklikheid, 'n geval van die 
ontdekking van die spesifieke rol wat ons gegee word om te speel - 'n rol wat heel moontlik deur die loop van jou lewe kan verskuif en verskillende vorme kan aanneem, terwyl ons ten volle gebruik maak van ons gawes in die dramatiese realisering van daardie rolle.

In my eie benadering tot praktiese teologie maak ek van die basiese kategorieë van drama gebruik om aan die hand van vier temas oor die gebied na te dink en navorsing te doen. In die kursus 'Inleiding tot Praktiese Teologie en Missiologie 112', maak ek gebruik van die verhoog om iets van die plaaslike, nasionale en internasionale konteks (kultuur) te verduidelik waarin ons teologiseer. As sogenaamde teks kyk ons na dissipelskap soos dit veral in die Nuwe Testament aan die orde kom en staan ons stil by verskillende komponente van wat dit beteken om navolgers van Christus te wees. Ons kyk na die optrede en lewe van die hoofakteur, Jesus Christus, op soek na koerswysers vir die ontwikkeling van die intrige. In die intrige staan ons stil by verskillende handelinge wat voortvloei uit dissipelskap, waaronder viering, verkondiging, lering, sorg, onderrig en diens. Dit help ons om die basiese struktuur van die drama te verstaan waarna ons almal genooi word om deel te neem. In die laaste deel kyk ons na die onderskeie rolle van die akteurs en na karakterontwikkeling aan die hand van verskillende gawes om uit te vind watter rol ons self in die drama kan en behoort te speel. Eersdaags behoort my boek te verskyn met die titel Saam in God se teater: Praktiese teologie in 'n Afrika-konteks (Nell in druk).

\section{Die impak van die COVID-19- pandemie op gemeentestudies}

Terwyl ek besig was om aan hierdie artikel te werk, het die COVID-19 pandemie in alle felheid toegeslaan en is ons op die oomblik midde-in die krisis. 'n Mens kan reeds massiewe veranderinge in die gemeentelike bediening sien sedert die COVID-19 in Suid-Afrika begin versprei het. Oornag moes predikante en kerkrade aanpas by die aanlyn modus van eredienste en kerkwees, en ek is baie seker dit sal 'n enorme verskuiwing in die bediening tot gevolg hê.

Ek het reeds 'n navorsingsvoorstel by die Universiteit Stellenbosch se Etiekkomitee ingedien met die titel 'COVID-19 en die impak daarvan op gemeentes: 'n Gevallestudie van die Stellenbosch Gereformeerde Ring'. Die navorsingsvraag kan soos volg gestel word: Wat is die impak van die COVID-19-pandemie op die gemeentelike bediening en wat is die grootste uitdagings wat predikante in hierdie tyd van onsekerheid in die gesig staar? Die doelstellings is om 'n beter begrip van die COVID-19-pandemie te ontwikkel deur 'n oorsig van sommige literatuur oor die aard van die krisis; om individuele kwalitatiewe onderhoude te voer onder 'n groep van 20 predikante om te poog om beter begrip te verkry van hul ervaring en begrip van die bediening sedert die uitbreek van die COVID-19-pandemie; en om enkele preke te ontleed wat die predikante gedurende die tyd van afsondering gelewer het om te kyk watter tekste hulle gebruik het (eksegese), hoe hulle dit met die COVID-19-krisis in verband gebring het (hermeneutiek) en om die Godsbeelde wat hulle gebruik het om die gemeente te vertroos beter te verstaan. Dit is vir my in elk geval op hierdie stadium reeds duidelik dat' $n$ mens vorentoe gaan praat van gemeentestudies voor en ná COVID-19.

\section{Gevolgtrekking}

In hierdie bydrae het ek begin deur eerstens te poog om die kontoere van wat ons verstaan deur die gebruik van die term 'gemeentestudies' te stip. Ons het gesien dat die meeste geleerdes saamstem met die vertrekpunt dat gemeentestudies bestaan uit 'n gedissiplineerde en holistiese ondersoek van gemeentes aan die hand van 'n verskeidenheid navorsingsmetodes en dat dit meer is as 'n paar los opmerkings oor wat in gemeentes gebeur. Ondersoeke in die gebied is daarop gemik om op 'n geordende wyse navorsing te doen oor wat werklik in groepe gebeur, sowel dít wat voor die hand liggend is as dít wat verborge is. Navorsers streef dus daarna om 'n akkurate weergawe te gee van die interaksie van verskillende aspekte van 'n gemeente op soek na bepaalde patrone en strukture.

Tweedens het ek probeer om 'n soort chronologiese oorsig van die gebied in die Suid-Afrikaanse konteks en spesifiek in die NG Kerk te gee. Ons het gesien dat die gebied begin het met navorsing oor gemeentebou en gemeentevernuwing, verskuif het na strategies teologiese beplanning, daarna na die dinamika en identiteit van geloofsgemeenskappe, met 'n verder fase met 'n spesifieke fokus op gemeentestudies in 'n Afrika-konteks, vervolgens ' $n$ fokus op empiriese navorsing en gemeente-ontledings, daarna die groot klem op die missionale aard van gemeentes, en laastens die fokus op ' $n$ teo-dramatiese benadering tot gemeentes. Ek het afgesluit met enkele opmerkings oor die impak van die COVID-19-pandemie. Die artikel dui op die rykdom van benaderings en die verskeidenheid metodes van ondersoek op 'n relatiewe jong veld van ondersoek wat steeds aan die ontwikkel is.

\section{Erkenning Mededingende belange}

Die outeur verklaar dat hy geen finansiële of persoonlike verbintenis het met enige party wat hom nadelig kon beïnvloed in die skryf van hierdie artikel nie.

\section{Outersbydrae}

I.A.N. is die enigste outeur betrokke by die skryf van die artikel.

\section{Etiese oorwegings}

Hierdie artikel voldoen aan alle etiese standaarde vir navorsing sonder direkte kontak met mens of dier. 


\section{Befondsing}

Hierdie navorsing het geen spesifieke toekenning ontvang van enige befondsingsagentskap in die openbare, kommersiële of nie-winsgewende sektore.

\section{Data beskikbaarheidsverklaring}

Data-deling is nie van toepassing op hierdie artikel nie, aangesien geen nuwe data in hierdie studie geskep of ontleed is nie.

\section{Vrywaring}

Die sienings en menings wat in die artikel uitgedruk word, is dié van die outeur(s) en weerspieël nie noodwendig die amptelike beleid of posisie van enige geaffilieerde agentskap van die outeurs nie.

\section{Literatuurverwysings}

Algemene Sinode van die NG Kerk, 2013, Raamwerkdokument oor die missionale aard en roeping van die Nederduits Gereformeerde Kerk, besigtig 05 Februarie 2020 vanaf https://www.academia.edu/4751292/RAAMWERKDOKUMENT_OOR_DIE MISSIONALE_AARD_EN_ROEPING_VAN_DIE_NG_KERK.

Ammerman, N.T., 2009, 'Congregations: Local, social, and religious', in P.B. Clark (ed.), Oxford handbook of the sociology of religion, pp. 562-580, Oxford University Press, Oxford. https://doi.org/10.1093/oxfordhb/9780199279791.003.0032

Brouwer, R., 2009, Geloven in gemeenschap: Het verhaal van een protestantse geloofsgemeenschap, Kok, Kampen.

Browning, D.S., 1994, 'Congregational studies as practical theology', American Congregations 2, 192-221.

Burger, C., 1991, Die dinamika van 'n Christelike geloofsgemeenskap: Nuut gedink oor gemeentes, Lux Verbi, Kaapstad.

Burger, C., 1995, Gemeentes in transito: Vernuwingsgeleenthede in 'n oorgangstyd, Lux Verbi, Kaapstad.

Burger, C., 1999, Gemeentes in die kragveld van die Gees: Oor die unieke identiteit, taak en bediening van die kerk van Christus, BUVTON \& Lux Verbi, Kaapstad.

Callahan, K.L., 1983, Twelve keys to an effective church, Harper \& Row, San Francisco, CA.

Carroll, J.W. \& Dudley, C.S., 1986, Handbook for congregational studies, Abingdon Press, Nashville, TN.

De Roest, H., 2005, En de wind steekt op. Kleine ecclesiologie van de hoop, Meinema, Zoetermeer.

Gibbs, E. \& Bolger, R.K., 2005, Emerging churches: Creating Christian community in postmodern cultures, Baker Academic, Grand Rapids.

Gutmann, B., 1925, Gemeindeaufbau aus dem Evangelium: Grundsätzliches für Mission und Heimatkirche, 3. Aufl., Evangelisch-lutherische Mission, Leipzig.
Healy, N.M., 2000, Church, world and the Christian life: Practical-prophetic ecclesiology, vol. 7, Cambridge University Press, Cambridge. https://doi.org/10.10 17/CBO9780511605857

Hendriks, H.J. (red.), 1992a, Gemeentes vertel: Verandering in 'n Christelike geloofsgemeenskap, Lux Verbi, Wellington.

Hendriks, H.J., 1992b, Strategiese beplanning in die gemeente: Die beginsels en praktyk, van gemeentevernuwing, Hugenote Kollege, Paarl.

Hendriks, H.J., 2004, Studying congregations in Africa, Lux Verbi, Kaapstad.

Hendriks, J., 2008, Verlangen en vertrouwen, Uitgeefmij Kok ten Have, Deventer.

Hopewell, J.F., 1987, Congregation: Stories and structures, Fortress Press, Minneapolis.

Moltmann, J., 1978, The church in the power of the Spirit: A contribution to messianic ecclesiology, Fortress Press, Philadelphia, PA.

Nel, M., 1982, 'n Program vir vernuwing, ongepubliseerd, University of Pretoria, Pretoria.

Nel, M., 1994, Gemeentebou, Orion, Vereeniging.

$\mathrm{Nel}, \mathrm{M} ., 2004$, Who are we? Understanding and finding identity in the local church, Orion, Vereeniging.

Nel, M., Nell, I.A., Schoeman, J.H. \& Tucker, R., 2015, Identity-driven churches: Who are we, and where are we going?, Biblecor, Wellington.

Nell, I.A., 2015, 'Leadership in faith communities - Linking with word and sacrament', in $\mathrm{M}$. Nel, I. A. Nell, K. Schoeman \& R. Tucker (eds.), Identity-driven churches, pp. 349-362, Biblecor, Wellington.

Nell, I.A., Saam in God se teater: Praktiese teologie in 'n Afrika-konteks (in druk).

Nieman, J.R., 2012, 'Congregational studies', in B. Miller-McLemore (ed.), The Wiley Blackwell companion to practical theology, pp. 133-142, Wiley Blackwell, Chichester. https://doi.org/10.1002/9781444345742.ch12

Niemandt, N., 2007, Nuwe drome vir nuwe werklikhede: Geloofsgemeenskappe in pas met'n postmoderne wêreld, Lux Verbi, Kaapstad.

Niemandt, N. \& Claassen, M.K., 2012, 'Van instandhouding na gestuurdheid: Die buitelyne van 'n missionale teologie,' Kruisgewys 7(1), 4-6.

Osmer, R.R., 2005, The teaching ministry of congregations, Westminster John Knox Press, Louisville, KY.

Powell, R., Bellamy, J., Sterland, S., Jacka, K. \& Pepper, M., 2012, Enriching church life A guide to results from National Church Life Surveys for local churches, 2 nd edn. Mirrabooka Press, Sydney.

Schoeman, J.H., 2015a, 'The exploration of congregations in South Africa: A practical theological perspective', Acta Theologica Supplementum 22, 105-125.

Schoeman, J.H., 2015b, 'Describing a congregation - Looking for certain markers', in M. Nel, I.A. Nell, K. Schoeman \& R. Tucker (eds.), Identity-driven churches, pp. 363-371, Biblecor, Wellington.

Schwarz, F. \& Schwarz, C.A., 1984, Theologie des Gemeindeaufbaus: Ein Versuch, LitVerlag, Neukirchen-Vluyn.

Stokes, A. \& Roozen, D.A., 1991, 'The unfolding story of congregational studies', in C.S. Dudley, J.W. Carroll \& J.P. Wind (eds.), Carriers of faith: Lessons from congregational studies, pp. 183-192, Westminster John Knox Press, Louisville, KY

Sweet, L., 1999, Soul tsunami: Sink or swim in the millennium culture, Zondervan Publishing House, Grand Rapids.

Turner, R., 2015, 'Discovering the chruch's forgotten identity', in M. Nel, I.A. Nell, K. Schoeman \& R. Tucker (eds.), Identity-driven churches, pp. 372-384, Biblecor, Wellington.

Turner, V., 1969, The ritual process: Structure and anti-structure, Aldine de Gruyter, New Brunswick.

Von Balthasar, H.U., 1988, Theo-drama: Theological dramatic theory, vol. 1, Prolegomena Ignatius Press, San Francisco, CA. 